\title{
PENGARUH PENGELUARAN PEMERINTAH, INVESTASI, DAN TENAGA KERJA TERHADAP PERTUMBUHAN EKONOMI KOTA MANADO
}

\author{
Christian Lendy Koyongian, Paulus Kindangen, George M.V.Kawung \\ Fakultas Ekonomi dan Binis, Magister Ilmu Ekonomi dan Bisnis \\ Universitas Sam Ratulangi, Manado
}

\begin{abstract}
ABSTRAK
Pertumbuhan ekonomi yang tinggi menandakan bahwa perekonomian didalam suatu negara atau daerah mengalami perkembangan, sebab pertumbuhan ekonomi menerangkan atau mengukur prestasi dari perkembangan suatu perekonomian dalam suatu wilayah. Banyak variabel-variabel perekonomian yang mempengaruhi pertumbuhan ekonomi antara lain pengeluaran pemerintah, investasi, dan tenaga kerja. Kota Manado sebagai ibukota Provinsi Sulawesi Utara merupakan pusat perekonomian dan titik pertumbuhan (growth point) yang pengaruh kegiatan perekonomiannya akan mempengaruhi kabupaten/kota lainnya di Sulawesi Utara. Tujuan peneliatan ini untuk mengetahui mengetahui pengaruh pengeluaran pemerintah, investasi, dan tenaga kerja terhadap pertumbuhan ekonomi di Kota Manado. Teknis analisis yang digunakan adalah Regresi Linier Berganda/Ordinary Least Square (OLS). Hasil analisis menunjukan bahwa secara parsial atau sendiri dengan Uji t, variabel pengeluaran pemerintah tidak berpengaruh terhadap pertumbuhan ekonomi di Kota Manado sedangkan variabel investasi dan tenaga kerja berpengaruh dan signifikan. Hasil analisis secara simultan atau bersama-sama dengan Uji F menunjukan bahwa pengeluaran pemerintah, investasi, dan tenaga kerja berpengaruh terhadap pertumbuhan ekonomi di Kota Manado. Kontribusi yang diberikan oleh ketiga variabel bebas terhadap pertumbuhan ekonomi di Kota Manado ( $R$ Square) sebesar $65,8 \%$.
\end{abstract}

Kata Kunci : Pertumbuhan Ekonomi, Pengeluaran Pemerintah, Investasi, Tenaga Kerja, OLS

\begin{abstract}
High economic growth indicates that the economy within a country or region develop, because economic growth explains or measures the achievement of the development of an economy in a region. Many economic variables that affect economic growth include government spending, investment, and labor. Manado City as the capital of North Sulawesi province is the economic center and growth point which influence its economic activity will affect other regencies / cities in North Sulawesi. The purpose of this research is to know the influence of government expenditure, investment, and labor on economic growth in Manado City. Technical analysis used is Multiple Linear Regression / Ordinary Least Square (OLS). The results of the analysis show that partially or alone with the t- test, the government expenditure variables do not affect the economic growth in Manado City while the investment and labor variables are affect and significant, The analyze result with simultan or together with $\mathrm{F}$ test shows that government expenditure, investment, and labor influence on economic growth in Manado City. The contribution given by the three independent variables on economic growth in Manado City (R Square) is $65.8 \%$.
\end{abstract}

Keywords: Economic Growth, Government Expenditure, Investment, Labor, OLS 


\section{PENDAHULUAN}

\section{Latar Belakang Penelitian}

Otonomi daerah telah bergulir sejak tahun 2001 melalui dasar hukum UndangUndang Nomor 22 Tahun 1999 tentang Pemerintahan Daerah dan Undang-Undang Nomor 25 Tahun 1999 tentang Perimbangan Keuangan antara Pemerintah Pusat dan Daerah. Kedua Undang-Undang ini kemudian di revisi lagi menjadi Undang-Undang Nomor 32 Tahun 2004 tentang Pemerintahan Daerah dan Undang-Undang Nomor 33 Tahun 2004 (Darise, 2007).

Pelaksanaan otonomi daerah mengandung makna bahwa daerah, terutama kabupaten dan kota, yang ada di seluruh wilayah Indonesia diberikan kewenangan dan tanggung jawab sebesar-besarnya untuk mengelola keuangan daerah sesuai kebutuhan yang ada di daerah masing-masing. Meskipun sumber pendanaan untuk kegiatan pemerintahan dan pembangunan di daerah sebagian besar masih bersumber dari APBN atau pemerintah pusat melalui Dana Alokasi Umum (DAU), Dana Alokasi Khusus (DAK) dan Dana Bagi Hasil (DBH) namun pemerintah daerah juga diberikan keleluasaan untuk mendapatakan pendapatan daerah melalui pajak dan retribusi daerah yang termasuk dalam Pendapatan Asli Daerah.

Pengeluaran pemerintah, baik oleh pemerintah pusat maupun pemerintah daerah memberikan dampak dan pengaruh terhadap pertumbuhan ekonomi. Konsep-Konsep Keynesian menunjukkan bahwa peranan pemerintah sangat besar dalam menciptakan pertumbuhan ekonomi. (Murni, 2006).

Semangat otonomi daerah memacu seluruh stakeholder di daerah terutama pemerintah untuk meningkatkan kinerja perekonomian daerah. Salah satu faktor penting yang mempengaruhi pertumbuhan ekonomi adalah investasi atau penanaman modal. Teori Harrod-Domar menjelaskan agar perekonomian mengalami pertumbuhan secara terus menerus dalam jangka panjang maka dibutuhkan investasi. (Sukirno, 2006).

Peranan investasi dalam perekonomian sangat penting. Kehadiran para investor di daerah dalam rangka menanamkan modalnya akan berdampak terhadap terciptanya lapangan kerja baru, terbukanya kesempatan kerja, sehingga akan mampu mengurangi tingkat pengangguran. Apabila investasi meningkat dalam setiap periode maka hal tersebut akan semakin memberikan dampak yang positif bagi perkembangan ekonomi di daerah sehingga dari waktu ke waktu perekonomian akan mengalami pertumbuhan yang signifikan.

Keberhasilan otonomi daerah juga dapat dilihat dan diukur melalui keterkaitan dan pengaruh antara variabel-variabel makro ekonomi di daerah. Jika pengeluaran pemerintah, investasi, dan kuantitas atau pertumbuhan tenaga kerja berpengaruh positif terhadap pertumbuhan ekonomi maka dapat dikatakan bahwa perekonomian daerah dalam semangat otonomi daerah adalah berhasil. Hal ini mengindikasikan bahwa pertumbuhan ekonomi selalu menjadi tujuan utama dalam pembangunan ekonomi di daerah.

\section{Perumusan Masalah}

Berdasarkan Latar Belakang Masalah maka dapat dirumuskan masalah penelitian sebagai berikut : 
1. Apakah pengeluaran pemerintah memiliki pengaruh terhadap pertumbuhan ekonomi di Kota Manado ?

2. Apakah investasi memiliki pengaruh terhadap pertumbuhan ekonomi di Kota di Manado ?

3. Apakah jumlah tenaga kerja memiliki pengaruh terhadap pertumbuhan ekonomi di Kota Manado ?

Apakah pengeluaran pemerintah, investasi, dan jumlah tenaga kerja secara bersamasama atau simultan memiliki pengaruh terhadap pertumbuhan ekonomi di Kota Manado ?

\section{Tujuan Penelitian}

1. Untuk mengetahui pengaruh pengeluaran pemerintah terhadap pertumbuhan ekonomi di Kota Manado.

2. Untuk mengetahui pengaruh investasi terhadap pertumbuhan ekonomi di Kota di Manado.

3. Untuk mengetahui pengaruh jumlah tenaga kerja terhadap pertumbuhan ekonomi di Kota Manado.

4. Untuk mengetahui pengaruh pengeluaran pemerintah, investasi, dan jumlah tenaga kerja secara bersama-sama atau simultan terhadap pertumbuhan ekonomi di Kota Manado.

\section{Manfaat Penelitian}

Hasil penelitian ini diharapkan dapat bermanfaat :

1. Menjadi bahan masukkan bagi pemerintah Kota Manado atau pun daerah lainnya dalam menyusun perencanaan pembangunan terutama yang berkaitan dengan upaya meningkatkan pertumbuhan ekonomi yang erat hubungannya dengan masalah dan variabel-variabel yang dipakai dalam penelitian ini.

2. Menjadi bahan referensi bagi penelitian lain demi pengembangan ilmu pengetahuan di bidang ekonomi pembangunan.

\section{KERANGKA PEMIKIRAN TEORITIS}

\section{Landasan Teoritis}

\section{Pengertian Pertumbuhan Ekonomi}

Istilah pertumbuhan ekonomi digunakan untuk menggambarkan terjadinya kemajuan atau perkembangan ekonomi dalam suatu negara atau daerah. Pertumbuhan ekonomi yang terjadi dalam suatu wilayah terkadang lambat terkadang juga mengalami kemajuan yang pesat. Suatu perekonomian dikatakan mengalami pertumbuhan, jika jumlah produk barang dan jasa atau dengan kata lain terjadi perkembangan Gross National Product potensial pada suatu negara. Pertumbuhan ekonomi harus mencerminkan pertumbuhan output per kapita. Terjadinya pertumbuhan per kapita berarti terjadi pertumbuhan riil dan meningkatnya standar hidup. Berdasarkan hal ini 
maka pertumbuhan ekonomi dapat didefinisikan sebagai : suatu kondisi terjadinya perkembangan Gross National Product potensial yang mencerminkan adanya pertumbuhan output per kapita dan meningkatknya standar hidup masyarakat (Murni, 2006 : 173).

\section{Pengeluaran Pemerintah}

Menurut Mankiw (2007) pengeluaran pemerintah merupakan salah satu komponen dalam permintaan agregat (aggregate demand), sebab apabila pengeluaran pemerintah meningkat maka permintaan agregat akan meningkat. Selain itu peranan pengeluaran pemerintah di negara berkembang sangat signifikan mengingat kemampuan sektor swasta untuk untuk mendorong pertumbuhan ekonomi masih sangat terbatas, sehingga peranan pemerintah masih sangat penting dalam perekonomian. Peningkatan permintaan berarti terjadi pertumbuhan ekonomi, karena pertumbuhan ekonomi diukur dari Produk Domestik Bruto (PDB).

Pengeluaran pemerintah (goverment expenditure) adalah bagian dari kebijakan fiskal (Sadono Sukirno, 2006) yakni suatu tindakan pemerintah untuk mengatur jalannya perekonomian dengan cara menentukan besarnya penerimaan dan pengeluaran pemerintah tiap tahunnya yang tercermin dalam dokumen APBN untuk nasional dan APBD untuk daerah/regional. Tujuan dari kebijakan fiskal ini adalah dalam rangka menstabilkan harga, tingkat output maupun kesempatan kerja dan memacu pertumbuhan ekonomi.

\section{Investasi}

Investasi merupakan salah satu faktor yang sangat berperan penting dalam pertumbuhan ekonomi suatu negara maupun daerah. Keberhasilan pertumbuhan PDRB, tidak dapat dipisahkan dari meningkatnya investasi. Investasi adalah kata kunci penentu laju pertumbuhan ekonomi, karena disamping akan mendorong kenaikan output secara signifikan, juga secara otomatis akan meningkatkan permintaan input, sehingga pada gilirannya akan meningkatkan kesempatan kerja dan kesejahteraan masyarakat sebagai konsekuensi dari meningkatnya pendapatan yang diterima oleh masyarakat.

Teori investasi adalah teori permintaan modal. Dalam makro ekonomi, investasi adalah arus pengeluaran yang menambah stok modal fisik. Lebih jauh disebutkan bahwa modal merupakan stok ketika nilai uang dari gedung-gedung, mesin-mesin, dan inventaris lain adalah tetap pada suatu waktu. Baik PDB maupun investasi mengacu kepada arus pengeluaran. Investasi adalah jumlah yang dibelanjakan sektor usaha untuk menambah stok modal pada periode tertentu.

\section{Tenaga Kerja}

Tenaga kerja merupakan sumber daya penting dalam pembangunan ekonomi. Tenaga kerja yang telah bekerja dan memiliki pendapatan akan memberikan kontribusi terhadap perekonomian sebab dengan pendapatan yang ada maka tenaga kerja tersebut akan melakukan konsumsi dengan melakukan pembelian atas barang dan jasa. 
Menurut Adam Smith dari aliran Klasik (dalam Lincolin Arsyad, 2004) pertumbuhan ekonomi dipengaruhi oleh dua faktor utama yakni pertumbuhan output total dan pertumbuhan penduduk. Laju pertumbuhan ekonomi sangat dipengaruhi oleh produktivitas sektor-sektor dalam menggunakan faktor-faktor produksinya. Produktivitas dapat ditingkatkan melalui berbagai sarana pendidikan, pelatihan dan manajemen yang lebih baik. Menurut Teori Pertumbuhan Ekonomi Klasik, pertumbuhan ekonomi bergantung pada faktor-faktor produksi (Sadono Sukirno, 2006). Unsur pokok dari faktor produksi suatu negara ada tiga :

1. Sumber daya alam yang tersedia merupakan wadah paling mendasar dari kegiatan produksi suatu masyarakat dimana jumlah sumber daya alam yang tersedia mempunyai batas maksimum bagi pertumbuhan suatu perekonomian.

2. Sumber daya insani (jumlah penduduk) merupakan peran pasif dalam proses pertumbuhan output, maksudnya jumlah penduduk akan menyesuaikan dengan kebutuhan akan tenaga kerja.

3. Stok modal merupakan unsur produksi yang sangat menentukan tingkat pertumbuhan output.

\section{Hubungan antara Pengeluaran Pemerintah dengan Pertumbuhan Ekonomi}

Menurut Teori Keynesian yang dipelopori oleh John Maynard Keynes bahwa dalam jangka pendek output nasional dan kesempatan kerja terutama ditentukan oleh permintaan agregat. Kaum Keynesian yakin bahwa kebijakan moneter maupun kebijakan fiskal harus digunakan untuk mengatasi pengangguran dan menurunkan laju inflasi. Konsep-konsep Keynesian menunjukkan bahwa peranan pemerintah sangat besar dalam menciptakan pertumbuhan ekonomi. Perekonomian pasar sepertinya sulit untuk menjamin ketersediaan barang yang dibutuhkan masyarakat dan bahkan sering menimbulkan instability, inequity, dan inefisiensi. Bila perekonomian sering dihadapkan pada ketidakstabilan, ketidakmerataan, dan ketidakefisienan jelas akan menghambat terjadinya pertumbuhan ekonomi dalam jangka panjang (Murni, 2006 : 183).

\section{Hubungan antara Investasi dengan Pertumbuhan Ekonomi}

Hubungan antara Investasi dengan pertumbuhan ekonomi dapat dijelaskan dengan teori Harrod - Dommar. Teori ini memberikan peranan kunci kepada investasi didalam proses pertumbuhan ekonomi, khususnya mengenai peran ganda yang dimiliki oleh investasi.

Dalam Teori Harrod-Domar investasi dan the incremental output ratio (ICOR) merupakan dua variabel fundamental (Tambunan, 2001). Investasi dimaksud adalah investasi netto, yaitu perubahan/penambahan stok barang modal, atau :

$I t=\Delta K t$

$I t=K t-K t-1$

ICOR adalah kebalikan dari rasio pertumbuhan output terhadap pertumbuhan investasi, yang pada intinya menunjukkan hubungan antara penambahan stok barang modal dan pertumbuhan output, atau melihat seberapa besar peningkatan investasi yang diperlukan 
untuk mendapatkan laju pertumbuhan ekonomi tertentu yang telah ditentukan sebelumnya. Hubungan tersebut dapat dijelaskan sebagai berikut :

$Y=y \cdot K$

$1 / y=K . Y$

Keterangan :

$y=$ rasio output - kapital

$1 / y=$ rasio kapital-output (COR)

$\mathrm{ICOR}=(\Delta K / Y) /(\Delta Y / Y)$ atau $I C O R=\Delta K / \Delta Y$

\section{Hubungan antara Tenaga Kerja dengan Pertumbuhan Ekonomi}

Hubungan antara tenaga kerja dengan pertumbuhan ekonomi dapat dijelasakan oleh Robert Solow dari MIT dan Trevor Swan dari Australian National University secara sendiri-sendiri mengembangkan model pertumbuhan ekonomi yang sekarang sering disebut dengan nama model pertumbuhan Neo-Klasik. Model Solow-Swan memusatkan perhatiannya pada bagaimana pertumbuhan penduduk, akumulasi kapital, kemajuan teknologi, dan output saling berinteraksi dalam proses pertumbuhan ekonomi. Dalam model Neo-Klasik dari Solow dan Swan dipergunakan suatu fungsi produksi yang lebih umum, yang bias menampung berbagai kemungkinan substitusi antara capital (K) dan tenaga kerja (L).

Fungsi produksinya adalah :

$\mathbf{Q}=\mathbf{F}(\mathbf{K}, \mathbf{L})$

Keterangan:

$\mathrm{Q}=$ Jumlah output yang dihasilkan

$\mathrm{f}=$ Fungsi

$\mathrm{K}=$ Kapital (modal sebagai input)

$\mathrm{L}=$ Labour (tenaga kerja, sebagai input) 


\section{Kerangka Konseptual}

Skema Kerangka Konseptual

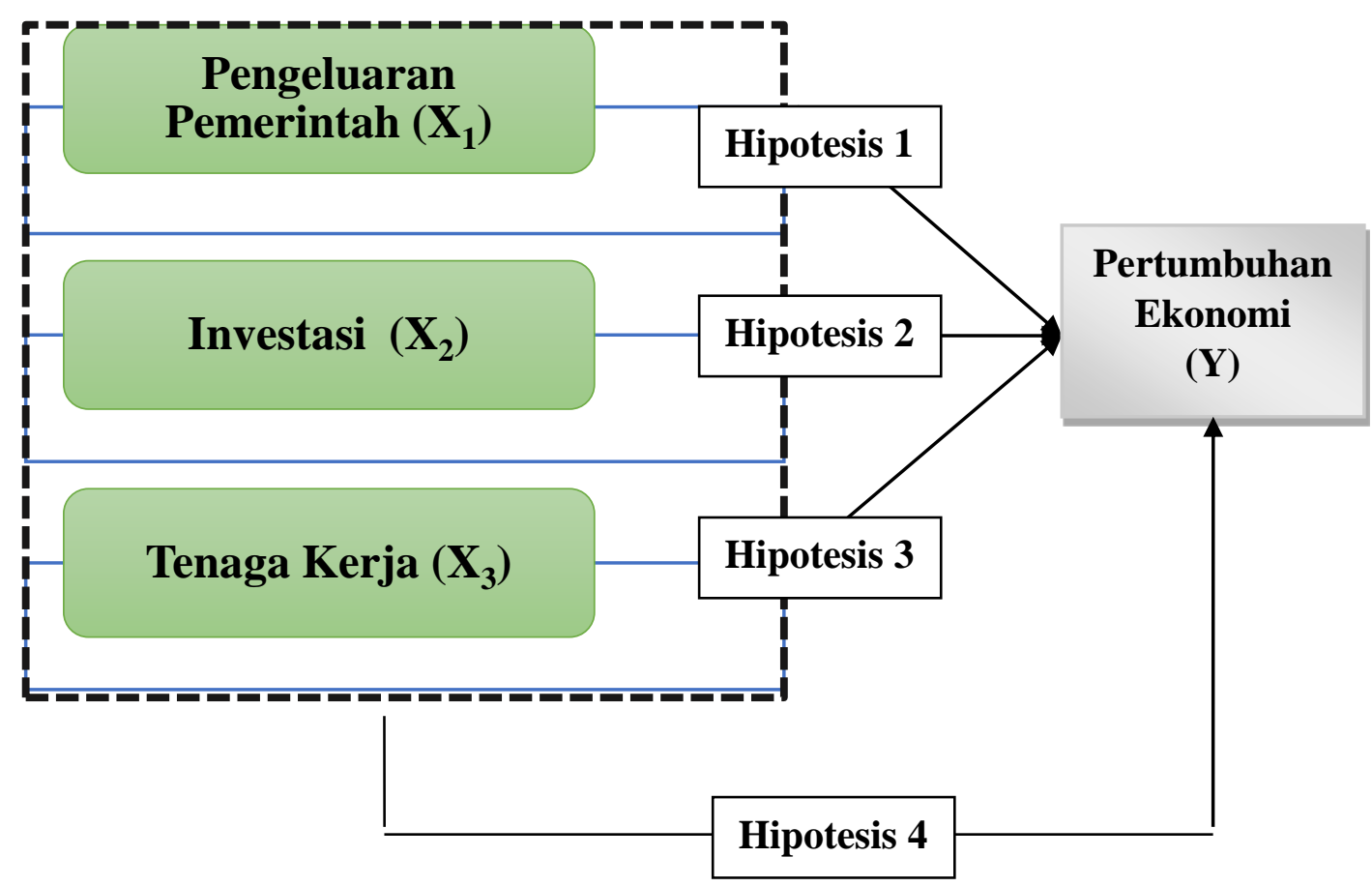

\section{Hipotesis}

Berdasarkan latar belakang, rumusan masalah dan landasan teoritis maka dapat dikemukakan hipotesis dari penelitian ini adalah sebagai berikut :

1. Diduga bahwa pengeluaran pemerintah memiliki pengaruh terhadap pertumbuhan ekonomi di Kota Manado.

2. Diduga bahwa investasi memiliki pengaruh terhadap pertumbuhan ekonomi di Kota Manado

3. Diduga bahwa tenaga kerja memiliki pengaruh terhadap pertumbuhan ekonomi di Kota Manado

Diduga bahwa pengeluaran pemerintah, investasi, dan jumlah tenaga kerja secara bersama-sama atau simultan memiliki pengaruh terhadap pertumbuhan ekonomi di Kota Manado.

\section{Data dan Sumber Data}

\section{METODE PENELITIAN}

Data yang digunakan dalam penelitian ini adalah data sekunder time series tahun 2006-2015 yang bersumber dari instansi yang memiliki kaitan dengan masalah dan variabel dalam penelitian ini antara lain dari Badan Pusat Statistik Kota Manado dan Propinsi Sulawesi Utara, Dinas Penanaman Modal Dan Pelayanan terpadu Satu Pintu Kota Manado, dan Bagian Keuangan Sekretariat Daerah Kota Manado. 


\section{Definisi Operasional dan Pengukuran Variabel}

Variabel yang digunakan dalam penelitian ini adalah sebagai berikut :

- Pengeluaran pemerintah ialah total realisasi pengeluaran atau belanja APBD pemerintah Kota Manado setiap tahun yang diukur dalam satuan Rp/tahun.

- Investasi ialah segala bentuk kegiatan menanam modal yang dilakukan oleh pengusaha baik itu pihak swasta maupun asing dalam rangka melakukan usaha pada berbagai sektor di Kota Manado setiap tahun yang diukur dalam satuan Rp/tahun.

- Tenaga kerja ialah jumlah orang berumur 15 tahun keatas baik laki-laki maupun perempuan yang bekerja pada berbagai sektor di Kota Manado yang diukur dalam satuan orang atau jiwa per tahun.

Pertumbuhan Ekonomi ialah pertumbuhan dari nilai riil perekonomian Kota Manado yakni pertumbuhan PDRB Riil (ADHK) setiap tahunnya yang diukur dalam satuan persen/tahun.

\section{Metode Analisis Data}

Metode analisis yang digunakan dalam penelitian ini adalah :

1. Analisis Deskriptif; metode ini berupa metode analisa tabel yang bertujuan untuk mengkaji dan menganalisa perkembangan yang terjadi dalam perekonomian di Kota Manado secara umum dan lebih khusus lagi mengenai perkembangan variabel pengeluaran pemerintah, investasi, jumlah tenaga kerja, serta pertumbuhan ekonomi.

2. Analisis statistik inferensia yang digunakan adalah analisis regresi berganda dengan persamaan sebagai berikut :

$$
\text { a. } \quad \mathbf{Y}=\boldsymbol{\beta o}+\boldsymbol{\beta}_{1} \mathbf{X}_{1}+\boldsymbol{\beta}_{2} \mathbf{X}_{2}+\boldsymbol{\beta}_{3} \mathbf{X}_{3}+\mathbf{e}
$$

kemudian data dilogaritmakan menjadi :

$$
\begin{aligned}
& \mathbf{L n Y}=\boldsymbol{\beta} \mathbf{0}+\boldsymbol{\beta}_{\mathbf{1}} \mathbf{L n} \mathbf{X}_{\mathbf{1}}+\boldsymbol{\beta}_{\mathbf{2}} \mathbf{L n} \mathbf{X}_{\mathbf{2}}+\boldsymbol{\beta}_{\mathbf{3}} \mathbf{L n X} \mathbf{X}_{\mathbf{3}}+\mathbf{e},(\text { full } \log ) \text { dimana }: \\
& \text { Ln }=\text { Logaritma } \\
& \text { Y }=\text { Pertumbuhan Ekonomi (Variabel Terikat) } \\
& \text { Bo }=\text { Konstanta } \\
& \beta_{1}, \beta_{2} \text {, dan } \beta_{3}=\text { Koefisien Regresi } \\
& \mathrm{X}_{1}=\text { Pengeluaran Pemerintah (Variabel Bebas 1) } \\
& \mathrm{X}_{2}=\text { Investasi (Variabel Bebas 2) } \\
& \mathrm{X}_{3}=\text { Jumlah Tenaga Kerja (Variabel Bebas 3) } \\
& \mathrm{e}=\text { Parameter Pengganggu }
\end{aligned}
$$

\section{HASIL PENELITIAN DAN PEMBAHASAN}

\section{Uji Asumsi Klasik}

Uji asumsi klasik dalam penelitian ini menggunakan bantuan software SPSS 17, dengan hasil sebagai berikut : 
a. Uji Autokorelasi

Hasil uji autokorelasi diperoleh nilai Durbin-Watson hitung sebesar :

\begin{tabular}{|l|}
\hline Durbin-Watson \\
\hline 2,025 \\
\hline
\end{tabular}

Hipotesis yang dikemukakan dalam uji autokorelasi adalah :

$\mathrm{HO}=$ tidak ada serial autokorelasi baik positif maupun negatif. Jika 4 -du $\leq \mathrm{d} \leq$ 4-dl berarti pengujian tidak meyakinkan atau tidak ada masalah autokorelasi. (Gujarati $2005: 218)$. Dengan $\mathrm{n}=10$ dan 3 variabel bebas $(\mathrm{k}=3)$ maka du $=$ $2,0163 \mathrm{dl}=0,5253$ maka $4-2,0163<2,025<4-0,5253$ sehingga $1,9387<$ $2,025<3,4747$. Berdasarkan hasil ini maka disimpulkan bahwa pengujian tidak terjadi masalah autokorelasi.

b. Uji Multikolinieritas

Uji Multikolinieritas dilakukan untuk melihat apakah ada keterkaitan antara hubungan yang sempurna antara variable-variabel independen. Jika didalam pengujian ternyata didapatkan sebuah kesimpulan bahwa antara variable independent tersebut saling terikat, maka pengujian tidak dapat dilakukan kedalam tahapan selanjutnya. Hasil uji multikolinieritas dalam penelitian ini adalah sebagai berikut :

\begin{tabular}{|c|c|c|}
\hline \multirow{2}{*}{ Model } & \multicolumn{2}{|c|}{ Collinearity Statistics } \\
\cline { 2 - 3 } & Tolerance & VIF \\
\hline Pengeluaran Pemerintah & 0,876 & 1,141 \\
\hline Investasi & 0,867 & 1,154 \\
\hline Tenaga Kerja & 0,925 & 1,081 \\
\hline
\end{tabular}

Hasil uji multikolinieritas menunjukkan bahwa nilai VIF dari variabel pengeluaran pemerintah, investasi, dan tenaga kerja adalah lebih kecil dari 10 dan nilai Tolerance lebih besar dari 0,10 . Hal ini menunjukkan bahwa tidak terjadi gejala multikolineritas didalam variabel penelitian ini.

c. Uji Heteroskedastisitas

Hasil uji heteroskedastisitas dalam penelitian ini adalah sebagai berikut : 


\section{Scatterplot}

Dependent Variable: PERTUMBUHAN EKONOMI

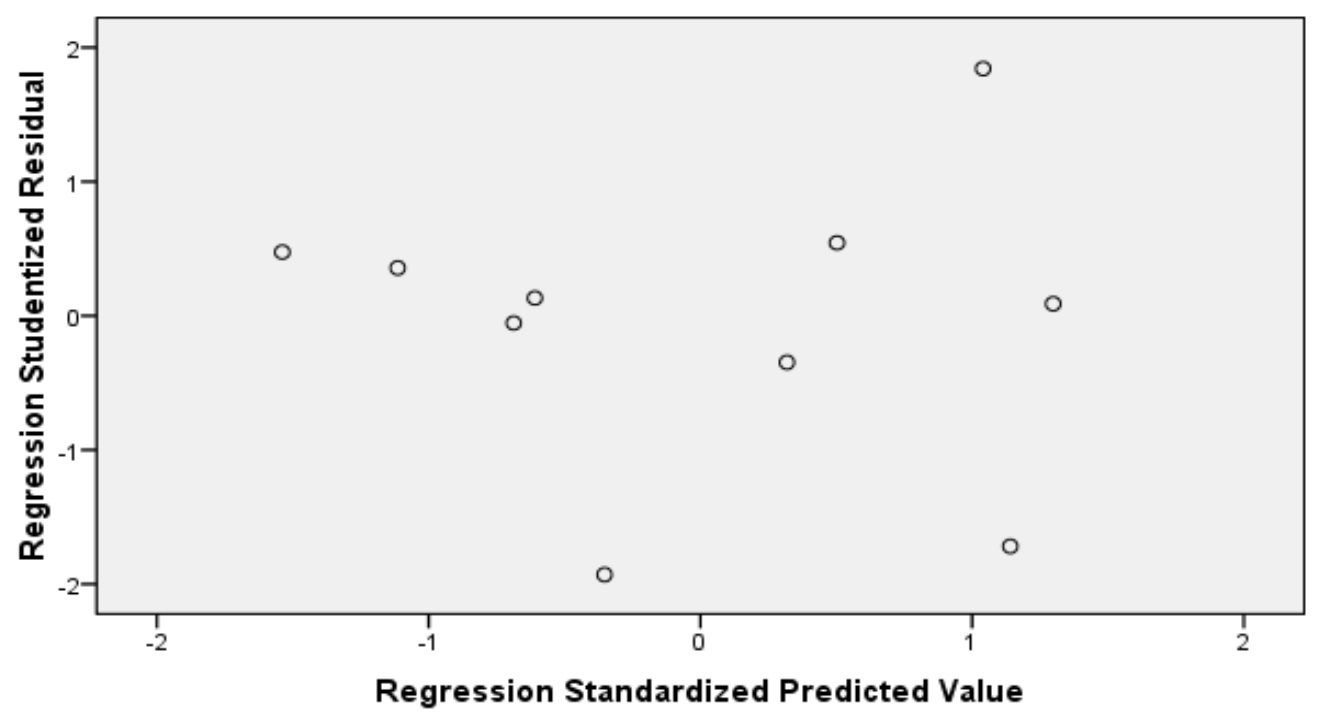

Hasil uji heteroskedastisitas memperlihatkan bahwa sebaran residual dalam scatterplot terpencar tidak beraturan atau tidak membentuk suatu pola tertentu yang rapi dan teratur. Oleh karena itu berdasarkan hal ini maka di dalam penelitian ini tidak terjadi gejala homokedastisitas atau persamaan memenuhi asumsi heterokedastisitas.

\section{Uji Normalitas Data}

Uji normalitas data bertujuan untuk menguji data-data tentang variabel yang digunakan dalam penelitian ini apakah sudah tersebar secara normal atau tidak. Sebelum digunakan dalam model regresi berganda maka variabel-varibel penelitian perlu di uji kenormalan datanya. Asumsi yang digunakan adalah bahwa data peneltian adalah data yang tersebar secara normal atau tersebar mendekati sumbu regresi. Uji normalitas data dalam penelitian ini menggunakan Test Kolmogorov-Smirnov dengan Software Program SPSS 17. Hasil uji normalitas data adalah sebagai berikut : 
One-Sample Kolmogorov-Smirnov Test

\begin{tabular}{|c|c|c|c|c|c|}
\hline & & $\begin{array}{c}\text { PENGELUARAN } \\
\text { PEMERINTAH }\end{array}$ & INVESTASI & $\begin{array}{l}\text { TENAGA } \\
\text { KERJA }\end{array}$ & $\begin{array}{c}\text { PERTUMBU } \\
\text { HAN } \\
\text { EKONOMI }\end{array}$ \\
\hline \multicolumn{2}{|l|}{$N$} & 10 & 10 & 10 & 10 \\
\hline \multirow[t]{2}{*}{ Normal Parameters ${ }^{\mathrm{a}, \mathrm{b}}$} & Mean & $2,742.40$ & $2,429.60$ & $1,205.40$ & 196.60 \\
\hline & $\begin{array}{l}\text { Std. } \\
\text { Deviation }\end{array}$ & 37.164 & 181.105 & 4.600 & 11.227 \\
\hline \multirow{3}{*}{$\begin{array}{l}\text { Most Extreme } \\
\text { Differences }\end{array}$} & Absolute & .161 & .165 & .170 & .186 \\
\hline & Positive & .161 & .103 & .170 & .186 \\
\hline & Negative & -.092 & -.165 & -.152 & -.151 \\
\hline \multicolumn{2}{|l|}{ Kolmogorov-Smirnov Z } & .508 & .521 & .538 & .588 \\
\hline \multicolumn{2}{|l|}{ Asymp. Sig. (2-tailed) } & .958 & .949 & .934 & .934 \\
\hline
\end{tabular}

a. Test distribution is Normal.

b. Calculated from data.

Hasil uji normalitas data menunjukkan bahwa nilai Asymp. Sig. (2-tailed) untuk variabel pertumbuhan ekonomi adalah 0,934. Variabel pengeluaran pemerintah sebesar 0,958. Variabel investasi sebesar 0,949 dan variabel jumlah tenaga kerja sebesar 0,934. Oleh karena keempat variabel memiliki nilai Asymp. Sig. (2-tailed) lebih besar dari 0,05 maka dapat disimpulkan bahwa data yang digunakan dalam penelitian ini tersebar secara normal.

\section{Hasil Uji Regresi Berganda dan Pengaruh Secara Parsial (Uji t)}

Hasil uji regresi berganda dan parsial adalah sebagai berikut :

\begin{tabular}{|c|c|c|c|c|c|}
\hline \multirow[t]{2}{*}{ Model } & \multicolumn{2}{|c|}{$\begin{array}{c}\text { Unstandardized } \\
\text { Coefficients }\end{array}$} & \multirow{2}{*}{$\begin{array}{c}\begin{array}{c}\text { Standardized } \\
\text { Coefficients }\end{array} \\
\text { Beta }\end{array}$} & \multirow[t]{2}{*}{$\mathrm{t}$} & \multirow[t]{2}{*}{ Sig. } \\
\hline & B & Std. Error & & & \\
\hline (Constant) & -1679.471 & 794.117 & & -2.115 & .079 \\
\hline PENGELUARAN & -.066 & .077 & -.271 & -.850 & .428 \\
\hline PEMERINTAH & & & & & \\
\hline INVESTASI & .039 & .016 & .621 & 2.421 & .052 \\
\hline TENAGA KERJA & 1.628 & .606 & .667 & 2.685 & .036 \\
\hline
\end{tabular}

Berdasarkan tabel diatas maka Persamaan Regresi dari penelitian ini adalah

$\hat{\mathbf{Y}}=-1679,471-0,066$ Pengeluaran Pemerintah + 0,039 Investasi $+1,628$ Tenaga

\section{Kerja}


Interpretasi dari persamaan regresi tersebut diatas adalah sebagai berikut :

- Nilai konstanta $-1679,471$ mengandung arti jika pengeluaran pemerintah, investasi, dan jumlah tenaga kerja $(\mathrm{X} 1, \mathrm{X} 2, \mathrm{X} 3)$ bernilai 0 atau $=0$ maka pertumbuhan ekonomi adalah sebesar $-1679,471$ persen.

- Nilai koefisien regresi pengeluaran pemerintah adalah sebesar -0,066. Hal ini mengandung arti jika pengeluaran pemerintah meningkat sebesar 1 persen maka pertumbuhan ekonomi juga akan menurun sebesar 0,066 persen.

- Nilai koefisien regresi untuk Investasi swasta sebesar 0,039. Hal ini mengandung arti bahwa jika investasi swasta meningkat sebesar 1 persen maka pertumbuhan ekonomi akan meningkat sebesar 0,039 persen.

- Nilai koefisien regresi jumlah tenaga kerja sebesar 1,628 Hal ini mengandung arti bahwa jika jumlah tenaga kerja meningkat sebesar 1 persen maka pertumbuhan ekonomi akan meningkat sebesar 1,628 persen.

Pengaruh variabel bebas terhadap variabel terikat secara parsial atau sendiri-

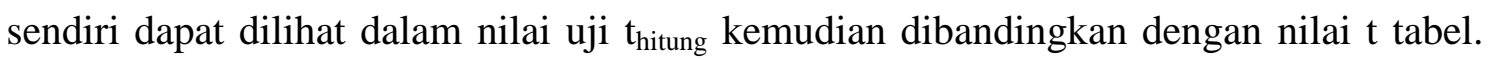
Hasilnya adalah sebagai berikut :

- Nilai thitung untuk variabel pengeluaran pemerintah adalah $-0,850$ sedangkan $\mathrm{t}_{\text {tabel }}$ dengan $\mathrm{n}=10$ tahun, 3 variabel bebas pada $\alpha=0,025\left(\alpha_{0,05 / 2} ; 10-3\right.$ menjadi $\alpha 0,025 ; 7)$ adalah sebesar : 2,365 Hasil ini menunjukan bahwa $t_{\text {hitung }}<t_{\text {tabel }}$ atau $-0,850<2,365$. Selain itu nilai Sig (Signifikansi) yaitu besaran nilai probabilitas adalah sebesar 0,428 atau lebih besar dari 0,05. Berdasarkan hasil perhitungan tersebut maka dapat diambil sebuah keputusan yaitu $\mathrm{H}_{0}$ diterima, dengan pengertian bahwa secara parsial pengeluaran pemerintah tidak memiliki pengaruh terhadap pertumbuhan ekonomi di Kota Manado.

- Nilai $t_{\text {hitung }}$ untuk variabel investasi adalah 2,421 sedangkan $t_{\text {tabel }}$ dengan $n=$ 10 tahun, 3 variabel bebas pada $\alpha=0,025\left(\alpha_{0,05 / 2} ; 10-3\right.$ menjadi $\left.\alpha 0,025 ; 7\right)$ adalah sebesar : 2,365 Hasil ini menunjukan bahwa $t_{\text {hitung }}>\mathrm{t}_{\text {tabel }}$ atau 2,421 > 2,365. Selain itu nilai Sig (Signifikansi) yaitu besaran nilai probabilitas adalah sebesar 0,052 atau sama dengan nilai signifikansi 0,05. Berdasarkan hasil perhitungan tersebut maka dapat diambil sebuah keputusan yaitu $\mathrm{H}_{0}$ ditolak, dengan pengertian bahwa secara parsial investasi memiliki pengaruh terhadap pertumbuhan ekonomi di Kota Manado dan pengaruhnya signifikan.

Nilai $t_{\text {hitung }}$ untuk variabel jumlah tenaga kerja adalah 2,685 sedangkan $t_{\text {tabel }}$ dengan $\mathrm{n}=$ 10 tahun, 3 variabel bebas pada $\alpha=0,025\left(\alpha_{0,05 / 2} ; 10-3\right.$ menjadi $\left.\alpha 0,025 ; 7\right)$ adalah sebesar : 2,365 Hasil ini menunjukan bahwa $t_{\text {hitung }}>t_{\text {tabel }}$ atau 2,685 $>2,365$. Selain itu nilai Sig (Signifikansi) yaitu besaran nilai probabilitas adalah sebesar 0,036 atau lebih kecil dari 0,05. Berdasarkan hasil perhitungan tersebut maka dapat diambil sebuah keputusan yaitu $\mathrm{H}_{0}$ diterima, dengan pengertian bahwa secara parsial jumlah tenaga kerja memiliki pengaruh terhadap pertumbuhan ekonomi di Kota Manado dan pengaruhnya signifikan. 


\section{Pengaruh Variabel Bebas Secara Bersama-Sama atau Simultan Terhadap Variabel Terikat (Uji F).}

Pengaruh pengeluaran pemerintah, investasi, dan tenaga kerja secara bersamasama terhadap pertumbuhan ekonomi di Kota Manado dapat dilihat dalam hasil uji nilai

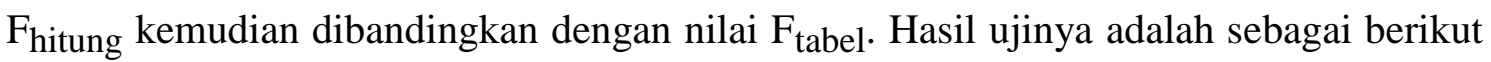

\begin{tabular}{|ll|l|l|l|l|l|}
\hline \multicolumn{2}{|c|}{ ANOVA $^{\mathbf{b}}$} \\
\hline 1 & & Sum of Squares & Df & Mean Square & F & Sig. \\
\hline & Regression & 745.939 & 3 & 248.646 & 3.840 & $.076^{\text {a }}$ \\
& Residual & 388.461 & 6 & 64.744 & & \\
& Total & 1134.400 & 9 & & & \\
\hline
\end{tabular}

Berdasarkan tabel ANOVA tersebut maka dapat dianalisa sebagai berikut :

- Nilai $F_{\text {hitung }}$ adalah sebesar 3,840

Nilai $F_{\text {tabel }} 0,05$ untuk 3 variabel bebas $(\mathrm{N} 1=3)$ dengan $\mathrm{N} 2=10$ sehingga $(\mathrm{N} 2-\mathrm{N} 1-1)$ atau $(10-3-1=6)$. Artinya nilai $F_{\text {tabel } 0,05}$ dengan 3 variabel bebas dan $n=6$ adalah 3,22 .

Nilai $F_{\text {hitung }}(3,840)>$ Nilai $F_{\text {tabel }}(3,22)$, dengan demikian maka secara bersama-sama atau simultan pengeluaran pemerintah, investasi, dan tenaga kerja berpengaruh terhadap pertumbuhan ekonomi di Kota Manado.

\section{Korelasi Antara Variabel Bebas dengan Variabel Terikat}

Korelasi atau keeratan hubungan antara variabel bebas dengan variabel terikat dapat dilihat dalam besarnya hasil uji korelasi yakni uji R :

\begin{tabular}{|c|c|c|}
\hline $\mathrm{R}$ & $\mathrm{R}$ Square & Adjusted R Square \\
\hline 0,811 & 0,658 & 0,486 \\
\hline
\end{tabular}

Hasil uji $\mathrm{R}$ menunjukkan bahwa keeratan hubungan antara pengeluaran pemerintah, investasi, dan tenaga kerja yang berperan sebagai variabel bebas dalam penelitian ini dengan pertumbuhan ekonomi sebagai variabel terikat adalah sebesar 0,811. Hal ini berarti bahwa antara variabel bebas dengan variabel terikat terdapat hubungan yang erat dan bersifat positif. 


\section{Kontribusi Variabel Bebas Terhadap Variabel Terikat}

Kontribusi atau determinasi variabel bebas terhadap variabel terikat dalam penelitian ini dpat dilihat dalam uji determinan ( $R$ Square atau $\left.\mathrm{R}^{2}\right)$. Hasil yang tercantum dalam tabel diatas menunjukkan bahwa nilai $\mathrm{R}$ Square adalah sebesar 0,658 atau 65,8 \%. Hal ini berarti bahwa kontribusi pengeluarn pemerintah, investasi, dan tenaga kerja terhadap pertumbuhan ekonomi di Kota Manado adalah sebesar 65,8 \% sedangkan sisanya sebesar 34,2 \% disumbangkan oleh variabel lain yang tidak dianalisis dalam penelitian ini.

\section{Pembahasan}

Berdasarkan hasil penelitian ini, maka dapat dikatakan bahwa dalam sepuluh tahun terakhir (2006-2015) pengeluaran pemerintah, investasi dan tenaga kerja, memberikan pengaruh yang tidak terlalu besar dan tidak signifikan terhadap pertumbuhan ekonomi di Kota Manado. Dengan kata lain, ada variabel lain yang lebih dominan mempengaruhi pertumbuhan ekonomi dibanding ketiga variabel yang digunakan dalam model penelitian ini. contonya variabel konsumsi, tabungan, suku bunga, inflasi, ekspor, impor, dan lainnya.

\section{KESIMPULAN DAN SARAN}

\section{Kesimpulan}

Berdasarkan hasil penelitian dan pembahasan maka tujuan penelitian ini yakni untuk mengetahui pengaruh pengeluaran pemerintah, investasi, tenaga kerja, terhadap pertumbuhan ekonomi di Kota Manado periode tahun 2006 sampai dengan tahun 2015 dapat terjawab dengan kesimpulan sebagai berikut :

1. Pengeluaran pemerintah tidak memiliki pengaruh terhadap pertumbuhan ekonomi di Kota Manado

2. Investasi memiliki pengaruh terhadap pertumbuhan ekonomi di Kota Manado

3. Tenaga Kerja memiliki pengaruh terhadap pertumbuhan ekonomi di Kota Manado.

4. Secara bersama-sama pengeluaran pemerintah, investasi, dan jumlah tenaga kerja memiliki pengaruh terhadap pertumbuhan ekonomi di Kota Manado.

Hasil uji asumsi klasik menunjukan bahwa data dan variabel yang digunakan semuanya tidak memenuhi ekspektasi, dengan kata lain bahwa tidak terjadi masalah multikolioneritas, heterokedastisitas, dan autokorelasi.

Kontribusi yang diberikan oleh ketiga variabel bebas terhadap variabel terikatnya sebesar 65,8\%. Atau lebih dari setengah pertumbuhan ekonomi di Kota Manado merupakan kontribusi dari variabel pengeluaran pemerintah, investasi, dan tenaga kerja, sedangakan sisanya yang mempengaruhi pertumbuhan ekonomi di Kota Manado dipengaruhi oleh variabel-variabel lain diluar penelitian ini. Adanya pengaruh untuk variabel investasi dan tenga kerja sekaligus mendukung penelitian-penelitian terdahulu 
dengan jenis variabel yang sama maupun yang hampir sama dengan tempat penelitian yang berbeda.

\section{Saran}

Pemerintah Kota Manado harus lebih bijak untuk mengatur pengeluaran pemerintah seperti belanja kebutuhan publik, pemerintahan, dan pembangunan harus lebih banyak dibelanjakan di Kota Manado ketimbang di daerah lain, serta mengatur lagi pos anggaran belanja rutin pegawainya agar tidak terlalu besar selisihnya dengan belanja modal ataupun belanja publik. untuk Investasi perlu lebih digalakan dengan membangun atau menyiapakan infrastrukur penunjang investasi, mempermudah proses perizinan, memberantas segala pungutan liar terkait perizinan, mengadakan promosipromosi potensi investasi, dan menuntun selalu para pelaku usaha agar mau membuat dan menyampaikan Laporan Kegiatan Penanaman Modal usahanya aga pemerintah dapat memperoleh data valid dan melihat sejuah mana keputusan dapat diambil terkait investasi dan pertumbuhan ekonomi kedepannya yang pada akhirnya juga bertujuan agar penyerapan tenaga kerja semakin meningkat sehingga jumlah tenaga kerja akan semakin banyak yang terserap dalam berbagai sektor lapangan kerja yang ada di Kota Manado dan produktivitas dari para tenaga kerja juga meningkat serta kesejahteraan pekerja semakin baik.

\section{DAFTAR PUSTAKA}

Arsyad,L, 2004, Ekonomi Pembangunan Edisi ke-4, Penerbit STIE Yayasan Keluarga Pahlawan, Yogyakarta

Darise,Nurlan, 2007, Pengelolaan Keuangan Daerah, Penerbit PT.Indeks, Jakarta

Murni, Asfiah (2006), Ekonomika Makro, Penerbit PT.Rafika Aditama, Bandung.

Sukirno, Sadono, 2006, Makro Ekonomi Teori Pengantar, Edisi Ketiga, Penerbit PT.RajaGrafindo Persada, Jakarta.

Sukirno, Sadono, 2006, Makro Ekonomi Teori Pengantar, Edisi Ketiga, Penerbit PT.RajaGrafindo Persada, Jakarta. 